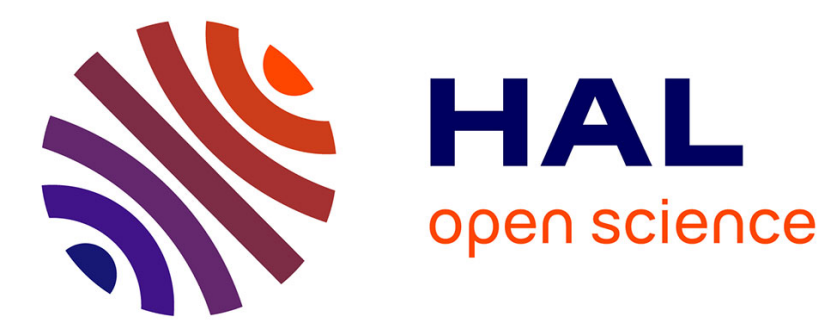

\title{
Tele-production of miningscapes in the open-pit era: The case of low-grade copper, Bingham Canyon, US and Chuquicamata, Chile (1903-1923)
}

\author{
Manuel Méndez, D. Galaz-Mandakovic, M. Prieto
}

\section{- To cite this version:}

Manuel Méndez, D. Galaz-Mandakovic, M. Prieto. Tele-production of miningscapes in the open-pit era: The case of low-grade copper, Bingham Canyon, US and Chuquicamata, Chile (1903-1923). The Extractive Industries and Society, 2021, 8 (4), pp.100830. 10.1016/j.exis.2020.10.013 . hal-03122747

\section{HAL Id: hal-03122747 \\ https://hal.science/hal-03122747}

Submitted on 2 Mar 2021

HAL is a multi-disciplinary open access archive for the deposit and dissemination of scientific research documents, whether they are published or not. The documents may come from teaching and research institutions in France or abroad, or from public or private research centers.
L'archive ouverte pluridisciplinaire $\mathbf{H A L}$, est destinée au dépôt et à la diffusion de documents scientifiques de niveau recherche, publiés ou non, émanant des établissements d'enseignement et de recherche français ou étrangers, des laboratoires publics ou privés. 


\title{
TELE-PRODUCTION OF MININGSCAPES IN THE OPEN-PIT ERA: THE CASE OF LOW-GRADE COPPER, BINGHAM CANYON, US AND CHUQUICAMATA, CHILE (1903-1923)
}

Manuel Méndez ${ }^{1,2}$, Damir Galaz-Mandakovic ${ }^{2}$ and Manuel Prieto ${ }^{3 *}$

${ }^{1}$ Université de Rennes 2, Laboratoire CReAAH-LAHM, Av. du Général Leclerc-CS 74205, 35042, Rennes Cedex, France.

2 Universidad Católica del Norte, Instituto de Arqueología y Antropología (IAA), Gustavo Le Paige 380, 1410000, San Pedro de Atacama, Chile.

${ }^{3}$ Universidad de Tarapacá, Departamento de Ciencias Históricas y Geográficas, 18 de Septiembre 2222, 1010069, Arica, Chile

* Corresponding author

E-mail addresses: manuel.mendez@univ-rennes2.fr (M. Méndez), damirgalaz@gmail.com (D. Galaz-Mandakovic) and mprieto@academicos.uta.cl (M. Prieto).

Keywords: Teleconnection; Miningscapes; Open-pit mining; Bingham Canyon; Chuquicamata; Copper Mining

\begin{abstract}
In 1906, the Guggenheim Exploration Company (GUGGENEX), financed the low-grade copper project that Daniel Cowen J ackling had started three years earlier at Bingham Canyon (Utah, US). With GUGGENEX's investment, the exploitation of copper entered into the open-pit mining era. Nine years later, the Guggenheim applied the industrial experience acquired in Bingham Canyon in the opening of the Chuquicamata Mine (northern Chile). In both cases, all the crucial decisions about the mining were made in Manhattan, New York, while the local territories faced these projects' outcomes. From a geohistorical standpoint, and through the analysis of several archives, in this paper, we explore how the extractive territories associated with these mines were remotely produced, transformed, and redefined; becoming "teleconnected miningscapes". We aimed to visualize how the cross-sector partnership between large economic groups-GUGGENEX-and scientific personalities was essential in the emergence of open-pit copper mining. We argue that the miningscapes produced in Bingham Canyon and Chuquicamata mines are an entanglement of scientific discourses, research (geology and metallurgy), materialities (capital and technology), human bodies (workers) and nature (copper porphyries, water, air, etc.) that were unevenly and remotely produced from the headquarters of GUGGENEX.
\end{abstract}




\section{Acknowledgements}

The authors appreciate the helpful comments from the three anonymous reviewers and the Guest Editor Iva Pesa. This research was funded by Laboratoire International Associé LIA Mines: archéologie, histoire et anthropologie des systèmes miniers dans le désert d'Atacama (CNRS-France); the Chilean National Agency for Research and Development (Agencia Nacional de Investigación y Desarrollo de Chile, ANID), FONDECYT 11180932, FONDECYT 1201527, FONDAP 15110006, PIA SOC180023; and Universidad de Tarapacá, Proyecto UTA Mayor 5784-20. An early version of this research was presented in the Workshop "Extractive Industries and the Environment: Production, Pollution and Protest from a Global and Historical Perspective". University of Oxford, December 2019.

\section{Introduction}

The Wall Street zone in the lower part of Manhattan, New York, has historically served as the administrative center of the US's economic power and, consequently, global capitalism. Indeed, the headquarters of the Morgan, Rothschild, Guggenheim, and Rockefeller families are located in this area.

The headquarters of the Guggenheim family (Meyer Guggenheim and Sons ${ }^{1}$ )-the most powerful economic group in the US in the $19^{\text {th }}$ and early $20^{\text {th }}$ centuries-were housed in an art deco building at 71 Broadway Street between 1899 and 1915. From the same building, the family operated the Guggenheim Exploration Company (GUGGENEX), created in 1899 with the aim of diversifying the family's mining business. The Guggenheims' major investment decisions were made, one after another, around the conference table in the meeting room. The modus operandi was always the same: a prolonged exposition about the technical characteristics of the ore, the production methods for its mining, and the refining process, followed by an economic feasibility study addressing investments, profits, management configuration, and other related matters. Meyer Guggenheim and Sons approved or rejected the mining development projects that the group was developing around the world, while the country's leading mining engineers informed the decision-making process. Among them, the figure of J ohn Hays Hammond stood out. Professor of Mining Engineering at Yale University and General Manager of GUGGENEX from 1903 to 1907, Hays Hammond was the most respected mining engineer in the US at the time.

Having initially rejected the Bingham mining project in 1900, by 1906, GUGGENEX had changed tack and decided to finance the mining experiment that the metallurgical

\footnotetext{
1 M. Guggenheim and Sons was comprised of Meyer, the patriarch of the family, and his sons Isaac, Daniel, Murry, Solomon, Benjamin, Simon, and William. Meyer was a Swiss citizen who arrived in the US in 1847. Over time, the family became known for its major enterprises, especially in the areas of mining and metal smelting (Grimm, 2002).
} 
engineer Daniel Cowen J ackling had started three years earlier in Bingham Canyon, Utah (Fig 1). Thus, the Guggenheims extended a crucial investment in the first exploitation of copper through open-pit mining. Nine years later and 8,300 km south, GUGGENEX applied all its industrial experience, acquired in the mining of the US's copper porphyries, to the opening of the Chuquicamata mine in the Atacama Desert (the current Antofagasta region of northern Chile) (Fig. 1).

In this paper, we seek to enrich the analysis related to the production of mining territories, or "miningscapes" (Stoltenborg \& Boelens, 2016; Méndez, Prieto \& Godoy, 2020). In so doing, we explore how certain miningscapes, in particular those connected through global capital, are in fact produced remotely. These remote connections imply administrative subordination and include a series of additional connections (technical, economic, material, discursive, and technological, among others) through which two distant territories function in a close relationship, or via "teleconnection." Specifically, we study the management of the two largest porphyry copper mines in the world: the Bingham Canyon and Chuquicamata open-pit mines. The size of the deposits was such that it required the investment of massive amounts of capital, the development of new technologies, and the work of the best geologists and metallurgical engineers at the time. Likewise, the execution of each of these projects required the transfer of an enormous amount of labor, as well as inputs from other territories, which transformed them into large-scale operations, while at the same time reconfiguring the power relations between the linked territories.

Thus, we suggest that the mining of porphyry copper is a historical assemblage of economic groups, porphyries minerals, hydrology, geology, political economy, scientific knowledge, labor, and power relations. Collectively, these factors were orchestrated by the Guggenheim family from the center of global economic power (Manhattan) in a quest to develop the world's largest copper mines at the time. ${ }^{2}$ We propose that the creation of a profitable business model to exploit copper porphyries ${ }^{3}$ required an alliance between capital-intensive companies and scientists with the necessary technical knowledge. For these case studies, the alliance between the Guggenheim family and a team of engineers led by Jackling represents a necessary cross-sector partnership that was integral to the realization of the open-pit copper mining model developed in Bingham Canyon. The same strategy was used for the Chuquicamata mining project nine years later. In both cases, even though the technical plans of the mining facilities and procedures were adapted to local social and environmental conditions, decisions about the major investments, technologies, management, and administration were made in Manhattan.

\footnotetext{
2 Our study covers the period up to the point that the Guggenheims sold Chuquicamata to the Anaconda Group (the world's second largest mining group at the time) in 1923.

${ }^{3}$ A porphyry rock is an ore body that contains two sizes of minerals-large crystals in a fine-grained matrix; the copper ore in porphyries is present in the fine matrix. The copper mineralization in copper porphyries can be present as oxides or sulfides. The principal characteristics of these copper porphyry ores are three-fold: the ore bodies have large volumes, the copper is low grade, and the copper is distributed relatively uniformly in the ore body (Parsons, 1933; Titley, 1972; Bridge, 2000).
} 
Concurrently, in the US and Chile, a magnified imaginary was created on North American engineers, who at the same time concealed the great number of workers laboring in highly dangerous conditions for minimal wages. In this context, in both Bingham Canyon and Chuquicamata, workers' resistance movements were violently suppressed with the help of the respective states.

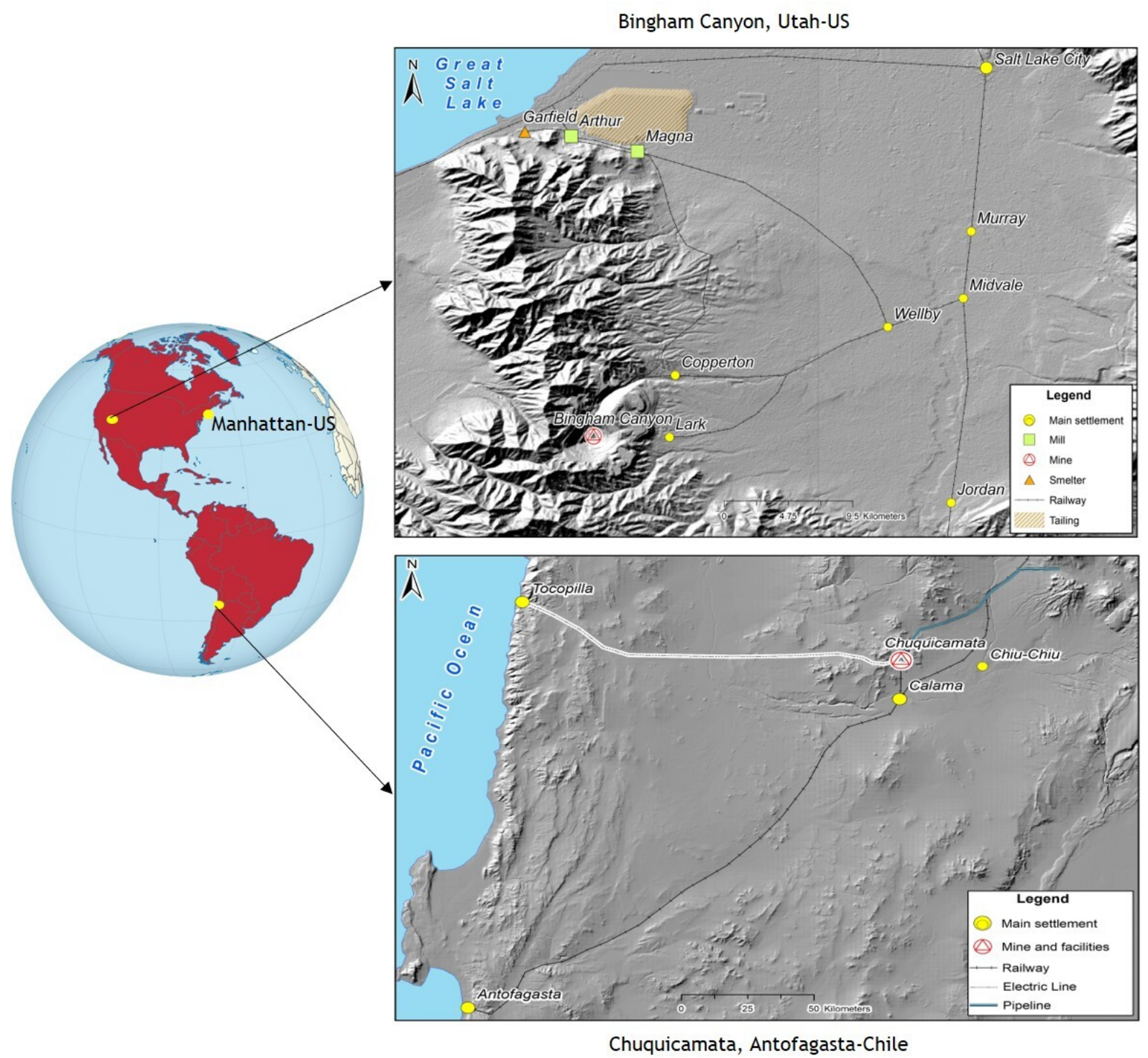

Fig. 1. General sketch of Bingham Canyon, Chuquicamata and the headquarters of GUGGENEX.

Source: Own elaboration on the basis of the Shuttle Radar Topography Mission (SRTM3)

(NASA/ NGA/ USGS); Parsons (1933) and Rudolph (1927).

\section{Teleconnections and the production of mining territories}

In the globalized world, the intensification of transport, technological innovations, media, investments, and international trade are all expanding and becoming 
increasingly complex, producing territories at multiple temporal and spatial scales. Within this scenario, there is a growing interest in understanding socio-environmental relations and their effects on connected territories (Adger et al., 2009).

To address these challenges, scholars have increasingly developed multidisciplinary conceptual frameworks to analyze what are often remote connections (e.g., Moore, 2000; Adger et al., 2008; Liu et al., 2013). Among other approaches, the use of the term "teleconnection" has a long history in climate research, designating the correlation between the fluctuations of specific meteorological parameters of widely separated points (Wallace \& Gutzler, 1981: 784). Studies of the relationship between meteorological parameters began at the end of the $19^{\text {th }}$ century and grew more complex in the 1920s. However, half a century later, Wright (1977) used the term "teleconnections" to describe these relations for the first time.

As proposed by Eakin et al. (2009: 400), the term teleconnections "is not explanatory in and of itself"; rather, it exposes a basic situation where there is an interrelation between two remote places in a given timeframe. This definition invites the use of the concept beyond the natural sciences. Indeed, Ross (2019) employs the term in order to describe the complex socio-environmental relations entangled in a globalized world. To this end, Ross (2019: 16) formulated the concept "material teleconnections" to describe the profound effects of long-distance trade, stressing how the distance between production and consumption can detach and bury the socio-environmental costs in the place of consumption.

The extensive potential uses for this concept led us to evaluate cross-scale territorial connections. We adopted it to analyze the configuration of different types of spatiotemporal relations between two distant places in the context of mining production. More specifically, we apply the concept to understand how two geographically distant territories are teleconnected by the same process of capitalist expansion in relation to the exploitation of minerals.

One of the consequences of growing Western economies and the technological advances of the late $19^{\text {th }}$ century was the expansion of the international metals market. This growth not only materialized through the exchange of the metals themselves but involved additional relationships and effects in terms of power, economics, environmental issues, and cultural and other factors (LeCain, 2009). In this context of "socio-environmental teleconnections," we propose that the implementation of open-pit copper mining produced new and teleconnected mining territories (miningscapes) in Utah and Atacama.

As noted earlier, by miningscapes we mean the socio-naturally produced territories that emerge from the historical entanglement between minerals, water, scientific discourse, state power, and capital accumulation (among other socio-natural factors, agents, and relationships), ensuring the transformation of minerals into commodities for global circulation (Stoltenborg \& Boelens, 2016; Méndez, Prieto \& Godoy, 2020). Consequently, in the context of existing miningscapes at Bingham Canyon and 
Chuquicamata, a new configuration of power relations and materialities was introduced and determined from an office in the heart of Manhattan.

Accordingly, we argue that the implementation of the mass production of copper was entangled with the installation of new power relations controlled from globalized economic power centers. Thus, even when the development of technology was adapted by the Guggenheim engineering staff to local socio-environmental settings, and as different labor and local resistance movements emerged, the imposition of a "technological rationality" (Marcuse, 2004: 146) ${ }^{4}$ was a condition of the planning, implementation, and operation of these mining territories. Furthermore, the mass production of copper was not possible without the incorporation of extensive levels of capital and territorial expansion of its exploitation, which led to the mass production of miningscapes. In this sense, the Guggenheim family's capital, together with science and the extensive incorporation of workers, produced a set of centrally exploited mining territories or a "teleconnected production of miningscapes." This idea invites exploration into how two geographically distant territories are jointly co-produced by capital as territories to be exploited or to produce the same commodities.

\section{The copper boom and the Guggenheim family}

In the early $19^{\text {th }}$ century, Cornish copper mining (southwest England) supplied most of the global demand for copper. Once Chile gained independence from Spain in 1810, English investors saw an opportunity to replace their declining copper production by sending miners and smelters from Cornwall to the new republic (Caldwell, 2015). This situation changed the global economy of copper: by 1850, Chile had become the world's leading producer, generating more than $50 \%$ of the world's copper. Later, when the copper mining boom began in the 1880s, this title was usurped by the United States. Following the irruption of copper porphyries into the metals market, the US and Chile led world production during the first half of the $20^{\text {th }}$ century.

In the final decades of the $19^{\text {th }}$ century, the inventions of Thomas Edison, Nikola Tesla, Alexander Graham Bell, and others promoted a revolution in the use of electricity in cities, which led to an increase in industrial production across the US and Europe. The widespread use of copper wires, electric motor components, brass (an alloy of copper and zinc extensively used in the expanding construction sector), and a plethora of copper pieces and devices significantly raised the demand for the red metal in North American and European markets (Parsons, 1933; Girvan, 1972; LeCain, 2009; Ross, 2019). At the same time, while the copper production rose steadily, the output struggled to meet global demand in this new era of electricity (Girvan, 1972).

\footnotetext{
4 Marcuse (2004) proposes that under technological rationality, the scientific conception of technology operates according to the laws of mass production and expediency in terms of profitable efficiency. Further, under this rationality, a hierarchy is established in terms of knowledge, where experts come to have greater decision-making power in society.
} 
In this promising economic context, copper seemed to be the "next opportunity metal" (Caldwell, 2015: 26), which encouraged the leading investors and companies in the US to turn their attention to copper mining. In a climate of broad corporate interests, the Guggenheim family had an early advantage, as it had been involved in the copper business since the beginning of the mining boom. In 1901, the Guggenheim family acquired a majority position in the American Smelting and Refining Company (ASARCO), a venture closely linked to their interest in copper. In the years that followed, GUGGENEX and ASARCO gained majority positions in several copper mines. By 1915, GUGGENEX's copper empire extended across seven US states (Alaska, Idaho, Nevada, Utah, Arizona, New Mexico, and Colorado), and included several mines in Mexico, Chile, and the Belgian Congo, making it the world's largest copper producer (Girvan, 1972). In late 1915, the Guggenheims dissolved GUGGENEX, concentrating their mining holdings in Kennecott Copper Corporation, created in conjunction with J.P. Morgan in April 1915 to merge mining projects in Alaska (Caldwell, 2014). At the end of 1922, even though Chuquicamata mine was their most productive project (see Fig. 2), the Guggenheims sold $51 \%$ of their shares to Anaconda for US $\$ 77$ million, selling their remaining 49\% in 1929 (Unger \& Unger, 2005). This deal put an end to the Guggenheim administration of Chuquicamata and marks the end of its control of the world's copper production.

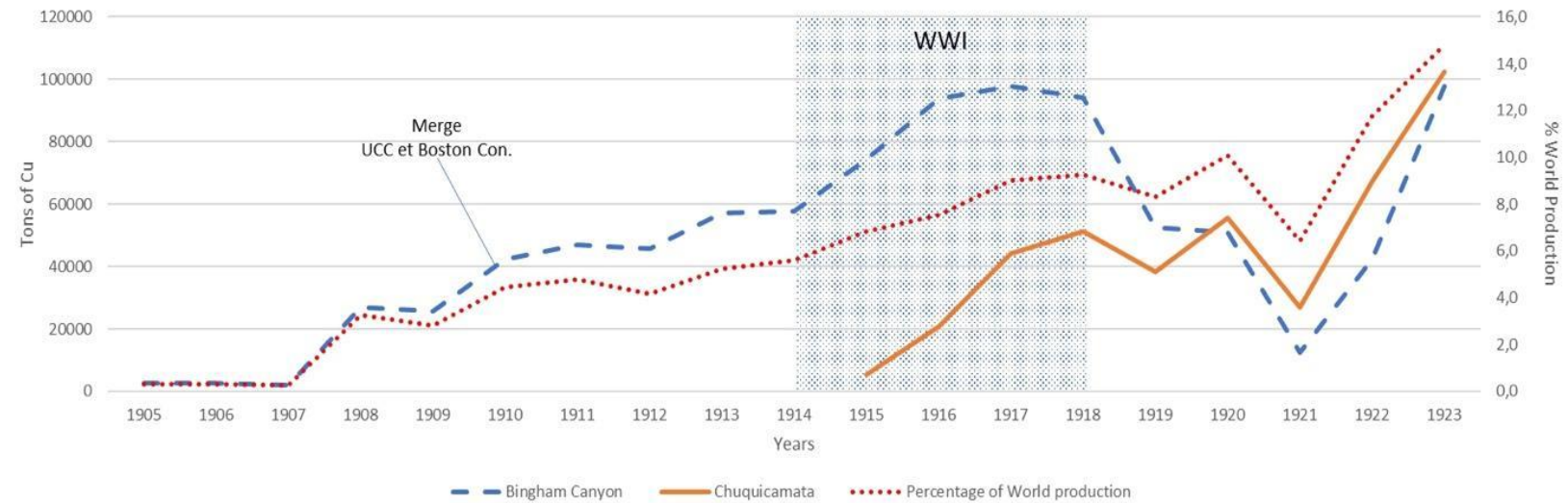

Fig. 2. Production at the Bingham Canyon and Chuquicamata copper mines. Source: Own elaboration on the basis of Parsons (1933: 6)

It took just three decades (1890 to 1920) for the introduction of capital-intensive investment and the development of cutting-edge technologies of extraction, processing, and enhancement of copper to completely transform the mode of producing the red metal. Owing to an offer-and-demand approach to scarcity, highgrade deposits were becoming progressively depleted (Ross, 2019), and production was not extensive enough to meet the mass consumption of copper. In this context, the next step for the industry was to exploit all potential sources of copper minerals, including the massive low-grade deposits of copper porphyries (Hyde, 1998).

Accordingly, the physicochemical characteristics of copper porphyries required new technical advances which, in turn, needed capital-intensive development in order to 
obtain profits from mining. This new scenario involved the participation of large economic groups that were able to finance the long process of mining development, hire the most advanced scientists at the time, ${ }^{5}$ and carry out the different procedures of milling, concentration, and smelting, alongside constructing machinery that could be adapted to the specific mineralogical characteristics of each low-grade ore.

\section{Bingham Canyon and Chuquicamata: The biggest pits in the world}

In 1900, the Guggenheims had chosen not to invest in the development of the Bingham Canyon or the Chuquicamata projects (O'Connor, 1937; Hoyt, 1967). However, the technological improvements achieved in the exploitation of copper porphyries during the first decade of the $20^{\text {th }}$ century, along with the potential to earn substantial profits, convinced them to construct the first open-pit copper mine in Bingham Canyon by 1906 and to develop the largest copper deposit in the world (Chuquicamata) by 1911. In what follows, we briefly discuss each deposit's historical origins, highlighting the pivotal role played by the input of intensive capital (GUGGENEX) in the largest open-pit copper mining projects of the time.

\section{1 The Bingham Canyon take-off and the open-pit era}

In 1848, the Bingham brothers (Thomas and Sanford) discovered the first mineral deposits of lead and silver in the Oquirrh Mountains of Utah. Despite these early discoveries, the West Mountain Mining District (later called the Bingham Canyon Mining District) was not established until 1863 (USGS, 1905).

In the years immediately following the establishment of the Bingham Canyon Mining District, several copper sulfide mines were exploited by artisanal miners or small companies (USGS, 1905). However, those years were recognized in mining yearbooks as the "silver-lead-gold period," due to the importance of these minerals for the district (Krahulec, 2010). The crucial period for copper mining in the district followed the economic crisis of 1893, after which several exploitation projects were undertaken, e.g., Utah Consolidated, Boston Consolidated and Utah Copper (Hansen, 1963).

In 1896, Thomas Weird and Samuel Newhouse created the Highland Boy Gold Mining Company to exploit the Highland Boy mine, discovered in 1873. In order to involve English capitalists, Weird and Newhouse founded Utah Consolidated Gold mines in Great Britain in 1896. At the beginning of the mine clearance works, miners discovered large amounts of copper sulfides with an average grade of around $25 \%$ causing a shift from gold to copper in the principal ore mined (Hansen, 1963). The first shipments of the red metal produced by Utah Consolidated are dated December 1896 (Rickard, 1932), making the Highland Boy mine the first extensive exploitation of copper in Bingham Canyon.

5 For example, GUGGENEX paid J.H. Hammond a higher salary than that of the US President at the time: US\$250,000 annually with shares in company ventures (Davis, 1989). 
After the success of Utah Consolidated, Newhouse and Weird partnered again to create another copper exploitation project: the Boston Consolidated Copper and Gold Mining Company Ltd. In 1898, they bought 65 claims in the Bingham Canyon sector known as the Copper Center Group. The operation would be carried out by the US branch, formed in November 1898-the Boston Consolidated Mining Company or Boston Con. (Arrington \& Hansen, 1963). In 1905, Boston Con. was planning open-pit operations for which they would use steam-shovels. ${ }^{6}$ By 1907, there were four steamshovels and 11 locomotives in use (Fig. 3), and the company finished their plant concentration by opening the Garfield mill (Parsons, 1933; Arrington \& Hansen, 1963).

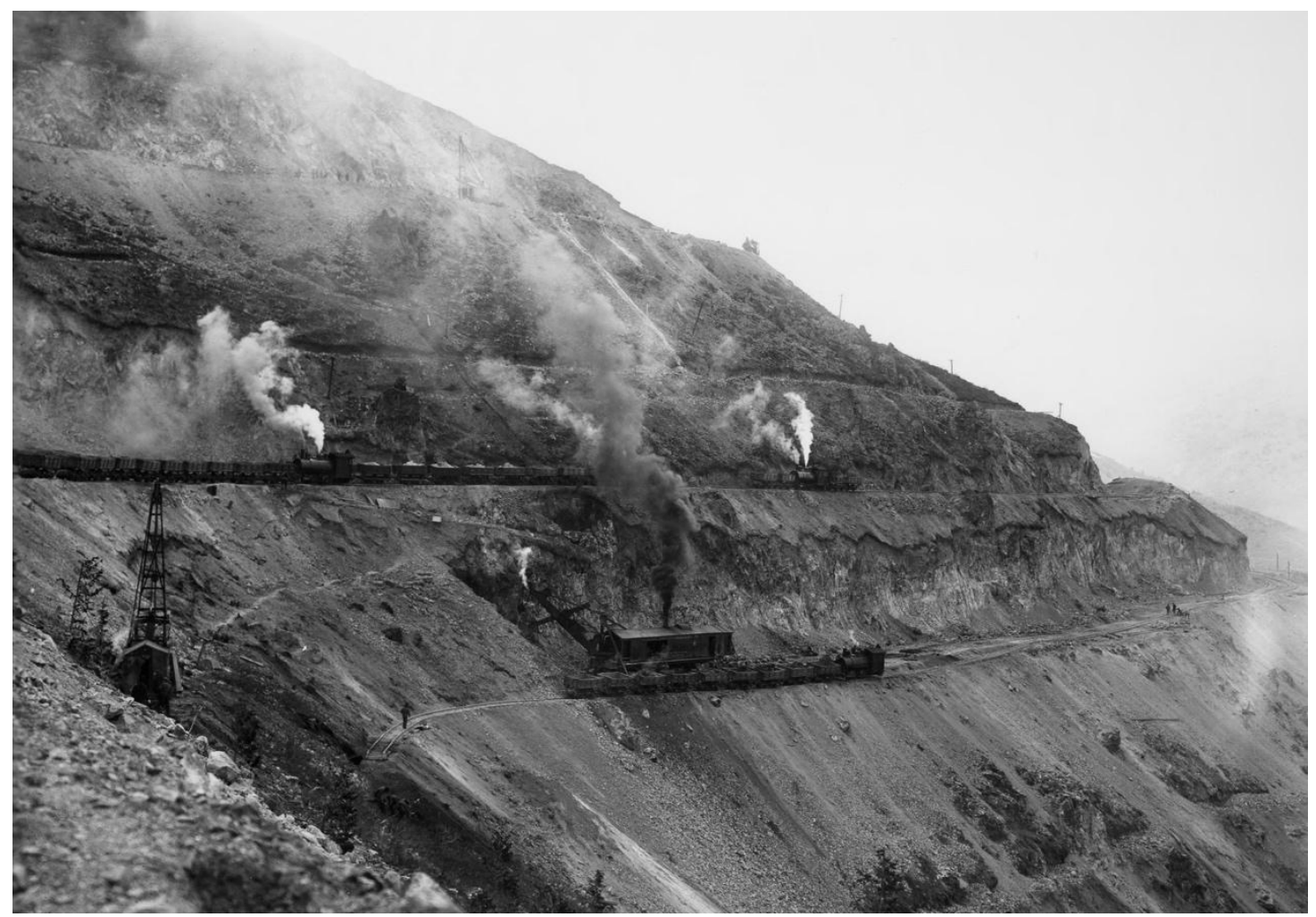

Fig. 3. Open-pit mining at Boston Con. mine, May 1907. Source: Utah State Historical Society (2008).

Photograph: Courtesy of the University of Utah, J. Willard Marriot Library [Utah State Historical Society]

In 1887, Enos Andrew Wall started to work at Bingham Canyon. Beginning with two, Wall quietly tested and bought several old claims. By 1896, he was the owner of 19 claims, corresponding to 200 acres. In 1899, Captain Joseph De Lamar sent two

\footnotetext{
6 In July 1905, Boston Con. sent representatives to examine the use of steam shovels in open-cut mining at the Sun Rise iron mine in Wyoming (Arrington \& Hansen, 1963). The earliest texts on Bingham Canyon used the term "open-cut" mining to describe the use of mechanical shovels in the extraction of minerals. Later, the concept "open-pit" was used to describe the extensive excavations carried out by this type of mass production mining. In this article, both concepts are used as synonyms.
} 
prominent engineers (Daniel C. J ackling and Robert C. Gemmell) to evaluate Wall's copper deposits and analyze his participation in the project (Hyde, 1998). Although the J ackling/Gemmell report was optimistic, De Lamar turned down the opportunity to get involved in the venture.

Having recognized the high value of the copper porphyries in Bingham Canyon, in the following years, J ackling convinced Spencer Penrose and Charles McNeill to negotiate an option on Wall's properties, and on J une 4, 1903, the Utah Copper Company (UCC) was created in Colorado with US\$500,000 in shares. Between 1903 and 1904, a 550 tons-per-day capacity pilot plant devised by Jackling was erected in Copperton (Parsons, 1933). The first test was successful, but UCC had invested all its capital in the development of Copperton Mill, so they had to search for new financial partners to develop this low-grade copper mining project.

After an initial refusal by Benjamin Guggenheim in 1900 (Hoyt, 1967), in 1905, Jackling convinced Daniel Guggenheim ${ }^{7}$ to consider the project. After a year of analyses, in 1906, GUGGENEX invested US\$5 million in the development of the mine and the purchase of equipment for open-pit mining, with the Guggenheims stipulating that ASARCO would take all the ore produced by UCC for 20 years. Consequently, in the same year (1906), ASARCO built a large smelter in Garfield, Utah (Fig. 1).

Even though Boston Con. had begun the exploitation of copper porphyries in Bingham Canyon District, ${ }^{8}$ it was the UCC that achieved greater success through their exploitation methods, becoming the first company to develop a profitable business model to exploit copper porphyries via open-pit mining. Furthermore, despite the fact that mineralogical reports had been revealing the huge scale of the UCC deposit since the 1890s, as well as the extensive technological development engaged in by Jackling and his team to exploit copper porphyries since early 1900s, the introduction of intensive capital was essential to the development of open-pit copper mining in Bingham.

\subsection{The introduction of Chuquicamata to the gl obal copper scene}

The first records of hand mining at Chuquicamata date from at least 1600 years before present (Figueroa et al., 2013). Later exploitation was associated with the Incas and the colonial period (see Parsons, 1933). Following the formation of modern states (beginning in the $19^{\text {th }}$ century), the greatest interest in exploitation emerged under the Chilean administration (CHILEX, 1958) in the wake of the Pacific War (1879-

\footnotetext{
7 Daniel Guggenheim was the primary shareholder in the family and the head of GUGGENEX. He was internationally known for his philanthropy and his power in the mining business. Daniel was a member of the National Security League, an organization that advocated for the US's entry into the Great War of 1914 (Hoyt, 1967).

8 Despite its spectacular beginning, by 1908, most of the extracted mineral was coming from the underground tunneling of sulfide ores (Arrington \& Hansen, 1963). In this context, Boston Con. was merged with the UCC in March 1910 (Parsons, 1933).
} 
1883). ${ }^{9}$ By the turn of the $19^{\text {th }}$ century, dozens of claims had been registered. Norman Walker (a Scottish merchant who lived in Antofagasta) was the first to attempt to merge these properties. He built a small treatment plant but lacked the necessary capital to continue exploiting the ore. Walker's intentions attracted the interest of a British company, Duncan, Fox \& Co., which funded the Antofagasta Copper Company in 1899 (Parson, 1933).

Numerous sources indicate that, in 1900, an employee of the Guggenheim family had recommended the purchase of this porphyry copper mine. This suggestion was quickly dismissed by the family, because at the time a profitable method for the extraction and refinement of copper porphyries had not yet been developed (O'Connor, 1937; Hoyt, 1967; O'Brien, 1989). In the meantime, Albert C. Burrage had become interested in the properties that Duncan, Fox \& Co. owned in Chuquicamata, sending the mining engineer Fritz Mella to evaluate the properties in 1911. At the same time, Pope Yeatman (at that time, director of GUGGENEX) sent Edwin S. Berry to evaluate the ore. After a short negotiation, Burrage decided to abandon the project, yielding his interests to GUGGENEX, which acquired total control by the end of 1911 (Parsons, 1933). ${ }^{10}$ In J anuary 1912, the Chile Exploration Company (CHILEX) was formed as a subsidiary of Chile Copper. ${ }^{11}$ Three months later, in April 1912, the GUGGENEX engineers Edwin Berry and Walter Perkins performed the first drilling test in Chuquicamata (Parsons, 1933).

Concurrently, the company began the process of buying all the mining claims around the principal project in order to centralize all the properties prior to undertaking the open-pit venture. ${ }^{12}$ Between 1911 and 1913, Duncan, Fox \& Co. managed the concessions or the lease of state lands to install production and logistics facilities. The company obtained access to more than 5,200 acres south of the Chuquicamata mine and the concession of coastal land in Tocopilla, where they planned to install a thermoelectric power plant (Orellana, 2004).

Regarding the procurement of water concessions for the Chuquicamata mine, the process involved more than two years of litigation with other actors located in the Loa River Basin. Duncan, Fox \& Co. requested the first concessions during the first half of 1911. After a series of oppositions and disputes with other water users-mainly the Antofagasta-Bolivia Railroad Co., Sloman \& Co., and an association of farmers from

\footnotetext{
9 The Pacific War was a conflict between the Peruvian-Bolivian confederation and Chile. One of the main causes of the conflict was the ownership and exploitation of saltpeter. After the war, Chile gained administration over the Litoral Department of Bolivia (the current Antofagasta region) and the Peruvian provinces of Arica and Tarapacá (Donald, 1936). For more information see Cluny (2000).

10 In 1908, the Guggenheim family acquired the majority position in the Braden Copper Co., which operated the El Teniente mine in southern Chile (Parson, 1933). With the materialization of the openpit project in Chuquicamata, the Guggenheims took complete control of large-scale copper mining in Chile.

11 The Chile Copper Company was established in April 1914, and the entire capital stock of CHILEX was transferred to this company (Unger \& Unger, 2005).

12 Martínez (1943) counted around 120 claims or concessions.
} 
Calama and Chiu-Chiu-the parties reached an agreement whereby the state granted a flow of 175 liters per second from the San Pedro River in November 1913. These waters were non-potable and thus suitable for mineral treatment (ARNAD-MINOP, 1911, 1912, 1913).

Since high-grade deposits are concentrated in particular locations, vein mining was developed in an atomized way. In this sense, both Bingham Canyon and Chuquicamata were subdivided due to the high level of competition allowed by the development of small- to medium-scale mining. As the technology of mining and processing low-grade ores advanced, various personalities began to assemble mining lands to exploit them individually (i.e., Bingham Canyon) or to speculate in the market for porphyry projects (i.e., A. Burrage at Chuquicamata). Both projects led to the accumulation of mining property by a few actors, a necessary step for the mass exploitation of porphyry copper.

\section{Open-pit miningscapes: Entanglements of nature, science, capital, and labor}

\section{1 Bingham Canyon and Chuquicamata territories as mining laboratories}

E. Wall conducted the first-and rudimentary-evaluations of the Bingham Canyon project. Between 1887 and 1896, he invested about US\$20,000 in the excavation of more than 3,000 feet in tunnels for the evaluation of his property (Parsons, 1933). In 1899, Jackling and Gemmell led an extensive geologic and economic evaluation of Bingham Canyon. These engineers developed a series of sampling methods, geological descriptions, volumetric estimations, and concentration tests for the porphyry ores. In addition, they calculated the economic profits and proposed open-pit mining as the only viable method for exploiting the ore, suggesting the utilization of steam-shovels and trains to extract and transport the minerals to the mills and smelters (Parsons, 1933; Krahulec, 2010). ${ }^{13}$

Up to this point, not all geological surveys were conducted by private interests. Following several fieldwork campaigns developed between 1900 and 1902, three USGS geologists (S. Emmons, A. Keith, and J. Boutwell) and a team of chemists, paleontologists, and assistants, completed a detailed report of the surface and underground geology of the entire district, which was published in 1905 (USGS, 1905). Before deciding to invest in the project, the Guggenheim family also undertook the development of new geological and economic studies. In 1905, J. H. Hammond (Consultant Engineer-in-Chief at GUGGENEX) directed Chester Beatty, Seeley W. Mudd, Henry Krumb, and 16 other junior engineers to develop a series of tests for the Utah Copper properties (Parsons, 1933; Unger \& Unger, 2005). After seven months and US\$150,000-worth of tests, the Guggenheim family decided to participate in the project (Parsons, 1933). Once the Guggenheims agreed to take on the Bingham

13 These propositions are striking, in the sense that the first open-pit mine project, which included the use of steam shovels on railway cars as the main excavation system, only began operating at the Iron Mesabi mine in 1902 (Kenneth, 1903). 
business, all significant mine changes or investment decisions were first evaluated by GUGGENEX engineers (Arrington and Hansen, 1963). Even if Jackling remained in charge of the Utah Copper Co., GUGGENEX's top engineers, J ohn Hays Hammond, Pope Yeatman, and Chester Beatty were among the company's managers and oversaw the actions of the mine (Parson, 1933).

Following the entry of the Guggenheims, the material flow of the raw ore was organized as follows. The extraction of raw material was carried out by steamshovels, which deposited the mineral directly into train convoys. These steam trains drove the material to the different mills: Copperton (until 1907), Magna, and Arthur. From the mills, the discarded material left the circuit (accumulated in the respective tailing), and the concentrate went to the Garfield smelter. As part of the merger between Utah Copper and Boston Con. in 1910, Jackling engaged an independent engineer to carry out detailed tests on the efficiency of both the Magna mill (built by UCC in 1906-1907) and the Arthur mill (originally named Garfield mill and built by Boston Con. in 1907, see Fig. 4). For one month, the two mills were fed the same type of ore. After an analysis of the results, the Magna plant was shown to recover the copper better and at lower operating costs. Accordingly, the Arthur mill was modified so that it could produce results equal to those at the Magna mill. The major modification was the replacement of the crushing system (Parsons, 1933). In 1917, the processing capacity of the Arthur mill was expanded, and a number of components involved in the concentration process were improved by UCC. These renovations enhanced the recovery of copper from the raw mineral. Furthermore, in 1919 the Magna mill was stopped, resuming operations in late 1922 (Parsons, 1933).

Between the first low-grade copper prospection in 1899 and the consolidation of the project in 1910, the different administrations employed eight of the 15 leading turnof-the-century US mining engineers (Caldwell, 2005). Bingham Canyon Mining District became an extensive testing ground for different methods and machinery to exploit the minerals (USGS, 1905; Parsons, 1933; Arrington \& Hansen, 1963). 


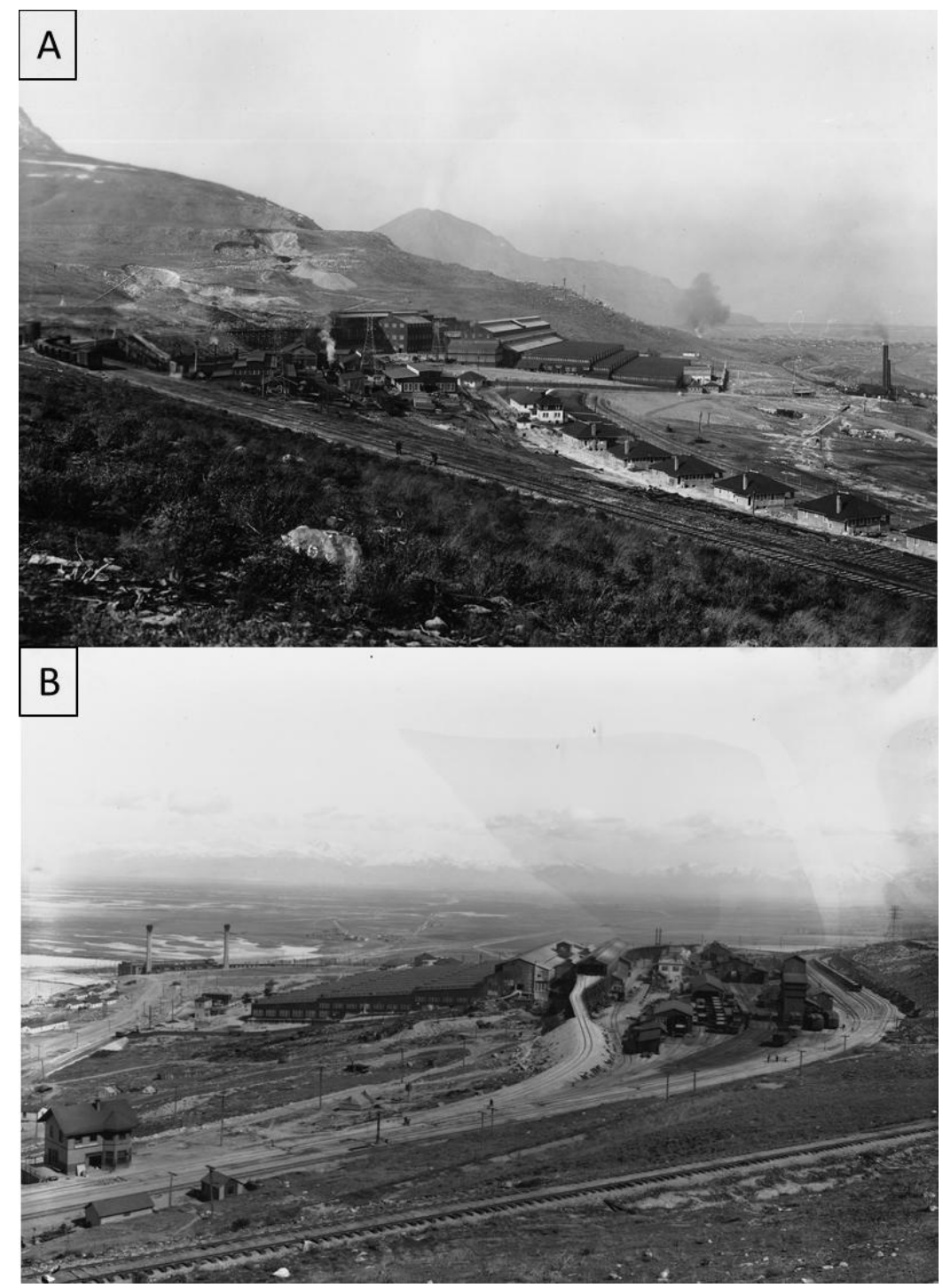

Fig. 4. Arthur (A) and Magna (B) mills, March 1914. Source: Utah State Historical Society (2008).

Photographs: Courtesy of the University of Utah, J. Willard Marriot Library [Utah State Historical Society].

In the case of the Chuquicamata mine, the first explorations of the project by the Guggenheims were requested by P. Yeatman and carried out on the ground by $E$. Berry in 1911 (Parsons, 1933). Once CHILEX was created, Berry and W. Perkins began exploration using a churn-drilling method in April 1912. After ten months of research and 54 churn-drill holes (MEW, 1914b), the engineers had verified the richness of the deposit, estimating the existence of 303 million tons with an average ore-grade of 2.3--2.8\% (Unger \& Unger, 2005). The cost of a year of drilling, first installations, supplies, and metallurgical tests amounted to US\$2,000,000 at the time (Parsons, 1933: 263). Based on different reports, CHILEX decided that the best extraction technique would be open-pit mining and its standard requirements: the use of steamshovels for extraction and a broad system for transporting the raw materials (Unger \& Unger, 2005). 
As with Bingham Canyon, underground exploration by mining engineers established the concentration and extent of the ore. In addition, they also carried out extensive chemical and metallurgical tests, two of which were developed by E. Cappelen-Smith at ASARCO sites (Flat River, Missouri, and Perth Amboy, New J ersey) and a third one directed by P. Yeatman in the facilities at Braden Copper (Chile). After extensive deliberations, the elite metallurgy engineers from GUGGENEX decided on the use of leaching and electrorefining as purifying methods (Parsons, 1933). Another example of the experiments conducted to set up the leaching process in Chuquicamata was the search for a coating that would allow the concrete tanks used in the process to contain sulfuric acid and extend their useful life. This treatment was developed by Trinidad Asphalt Mastic and Vulcanite Paving Co., under the direction of $\mathrm{H}$. Wiederhold and E. Cappelen-Smith, at the ASARCO laboratories at Maurer, New J ersey (MEW, 1914a).

After more than two years of research, experimentation, and tests, the mining process flow was established as follows. ${ }^{14}$ The raw material was extracted using steam-shovels and transported by train to the ore bins. From there, it was transferred to the crusher building on conveyor belts (Brushnell, 1915). Grinding was carried out in three successive steps using the following equipment: 1) McCully gyratory crushers, 2) Symon's disc crushers, and 3) Garfield roll crushers. Conveyor belts carried the crushed material to the leaching vats where the hydro-refining process would begin. After a few days of treatment, the liquid was piped to the dechlorination plant (MEW, 1915; Aiken, 1915) (see Fig. 5). Subsequently, the mixture was sent to the electrolysis plant, and from there the final refined copper was taken by the Antofagasta-Bolivia railway to the port of Antofagasta and transferred by boat (via the Panama Canal) to the US (MEW, 1914b).

\footnotetext{
14 The Chuquicamata mining methods were designed on the basis of a small-scale experiment (Parsons, 1933), which implied that the corrections of specific processes were made after their real operations began. In the case of Bingham Canyon, a pilot plant was designed and operated by D. J ackling before the construction of the principal facilities. The changes to the Bingham mining process that followed (1906-1923) were associated with an increase in capacity.
} 


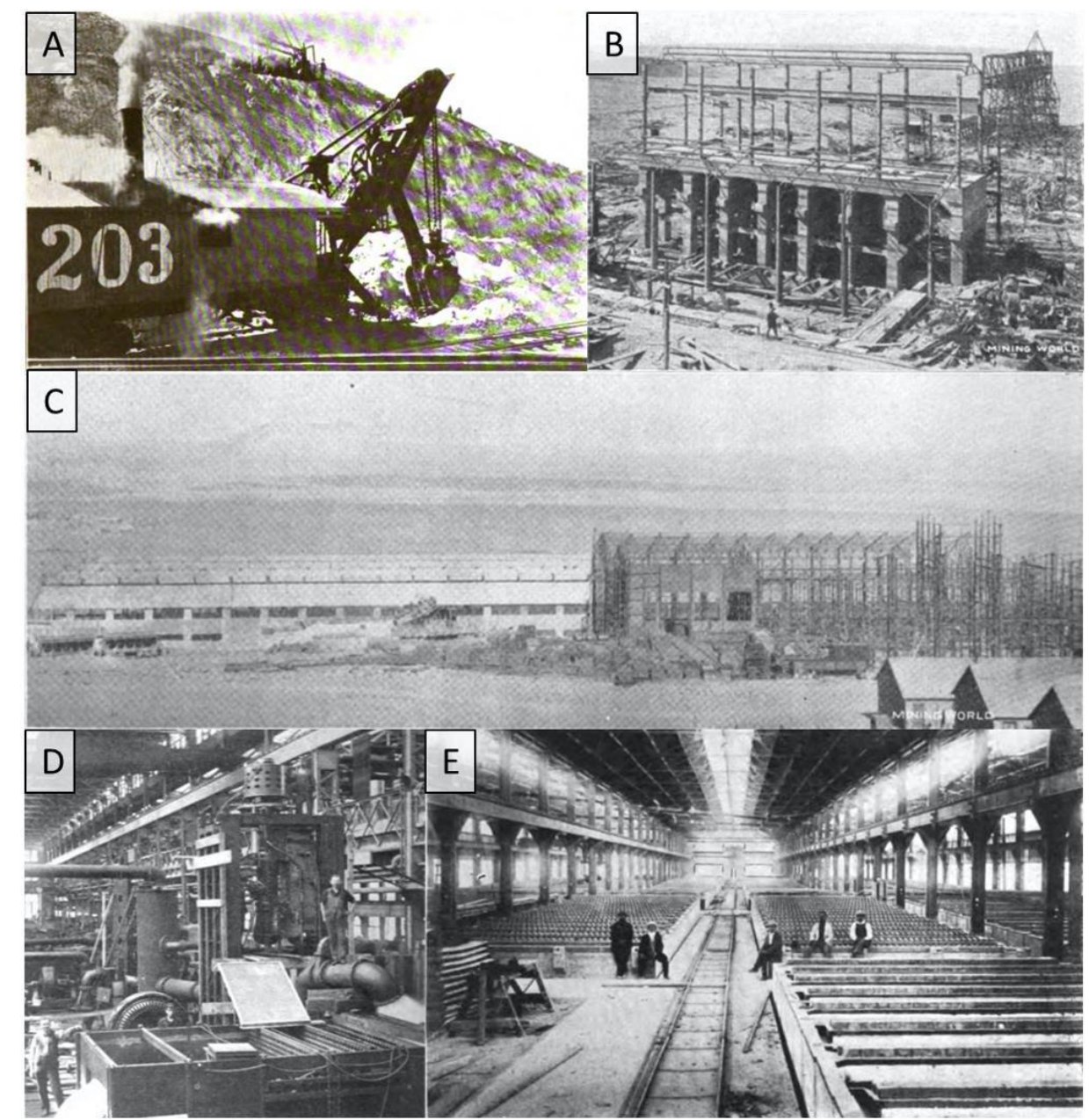

Fig. 5. Chuquicamata facilities under construction (1914).

A) Steam-shovel in testing, B) Crusher building, C) Leaching plant, D) Acid solution pump, E) Electrolytic plant.

Source: A) Brushnell, (1915: 205); B) MEW (1914: 948); C) Tupper (1914: 520); D) MEW (1915: 1124); E) Brushnell, (1915: 203).

All the facilities were powered by a thermoelectric plant installed for GUGGENEX at the port of Tocopilla (140 km from Chuquicamata) (see Fig. 6). The grid's electric cable system had to cross the coastal mountain range and arrive at Chuquicamata at 2,760 meters above sea level. This altitude implied that the insulators of the electrical transmission towers reached high temperatures, which would have compelled the engineers to conceive of new transmission towers and insulators (Brushnell, 1915). In 1913, high-voltage towers were installed and organized in three different lines (Illanes, 1915). The water concessions acquired by the company were situated on the San Pedro River (58 km northeast of the mine) in the middle of the Andes mountains. From this point, several pipe systems were installed to supply industrial water (Rudolph, 1951). Due to the amounts of nitrate present in these waters, potable water was carried from the springs of Paniri and Tatio by train during the first years of operations (Brushnell, 1915). 


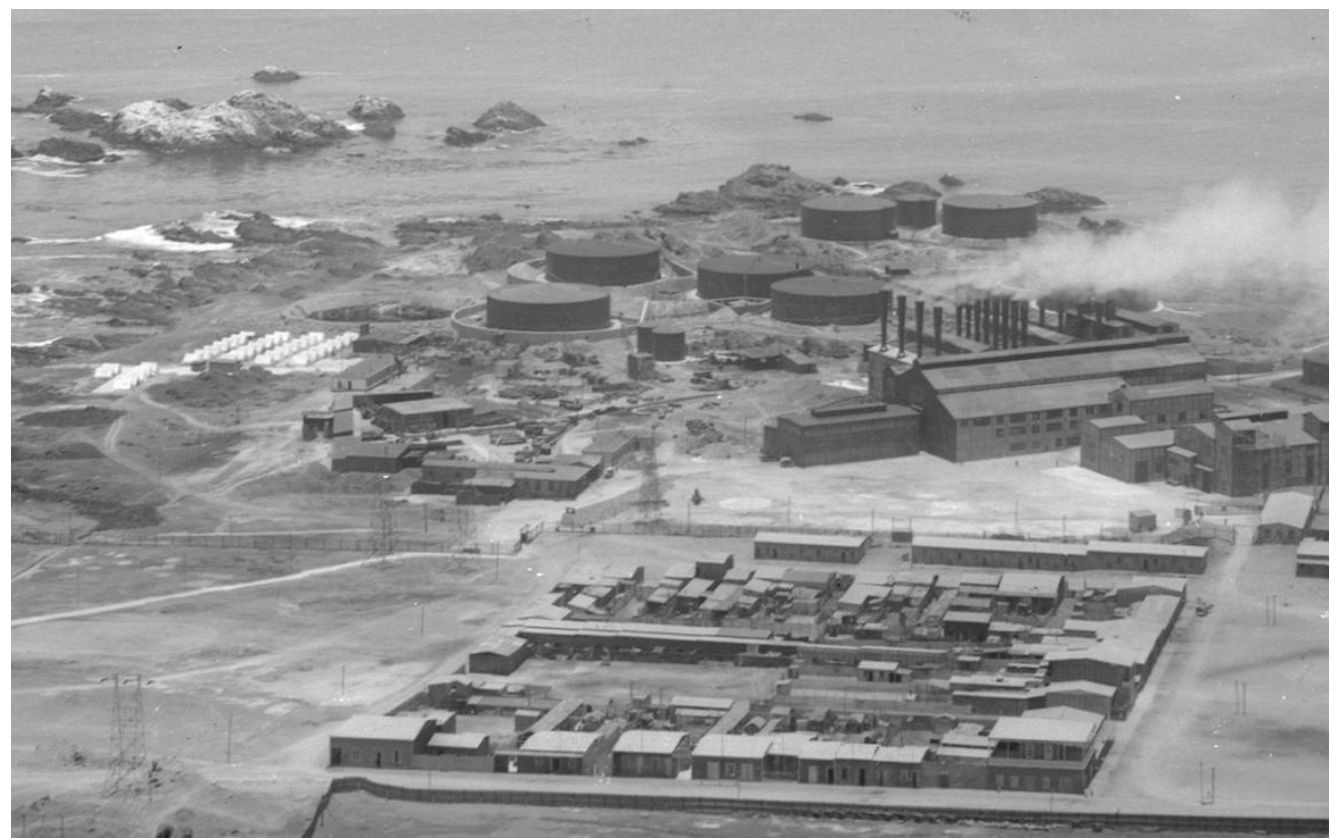

Fig. 6. Thermoelectric plant at Tocopilla (1915).

Source: Galaz-Mandakovic (2017: 122).

Finally, on May 18, 1915, then-President of Chile, Ramón Barros, accompanied by some members of the Guggenheim family, symbolically switched on the Tocopilla plant from the presidential palace in Santiago, sending the energy necessary to commence operations at Chuquicamata (Unger and Unger, 2005).

Following the first few months of work, managers of the operating system found that it was struggling to crush the rocks properly due to their unanticipated hardness. After several mechanical studies, in 1917, two jaw-breakers were installed as a first grinding line prior to the gyratory crushers, and suspension dust abatement systems were also incorporated (Parsons, 1933). In addition to the changes implemented to improve the mining process, some modifications were made by CHILEX with the aim of increasing production. After a couple of years of operations, the railway system installed to transport the material obtained through blasting into the refining facilities was extended to the tailing management. Additionally, the mine acquired an electric dumper, which was used to remove the ore from the cars, and by 1918 Chuquicamata was operating at its maximum capacity (Parsons, 1933).

In addition to making "legible" the underground territories (Braun, 2000; Méndez, Prieto \& Godoy, 2020), the long history of underground surveys at Bingham Canyon and Chuquicamata also transformed the subsoil into a mass of minerals that were accurately detailed in their mineralogical, metallurgical, and economic aspects. This socio-natural production of the underground territories was a crucial milestone in establishing mass extraction and processing procedures for copper porphyries. Indeed, from the very early stages of both projects, nothing was randomly developed. All 
technical decisions about the production process were thoroughly tested by a team of leading US mining experts before they were put into operation in Utah and Atacama. ${ }^{15}$

However, differences were also identified between the tele-production of these two miningscapes. In Bingham's case, the local engineering groups (led by Jackling) had absolute control over the technical tests and decisions before the arrival of the Guggenheim capital. Yet, following the Guggenheims' involvement, Jackling and his team were constrained by constant counter-evaluations by the GUGGENEX and later Kennecott expert groups (although their participation in the decisions was never overridden). In the Chilean case, though some field tests were conducted in the Atacama Desert, the entire staff in charge of the mine's administration came from the GUGGENEX ranks. Further, along with the mine's production facilities, modern communication installations were implemented between New York and Chuquicamata, to allow executives based in Manhattan to make faster decisions.

5.2 Technological rationality and the mass production of teleconnected miningscapes The success of the Bingham Canyon mine was greatly associated with the name of Daniel C. J ackling (Parsons, 1933; Arrington \& Hansen, 1963; Whitehead \& Rampton, 2006; Krahulec, 2010). Jackling obtained a BS degree in Mining and Metallurgy at the Missouri School of Mines at Rolla in 1889. ${ }^{16}$ He taught chemistry and metallurgy at the same school between 1891 and 1893. From 1893 to 1895, he was a mill-man and metallurgist at the Cripple Creek gold mine in Colorado. After this short career, J ackling achieved notoriety when, together with other engineers, he planned, tested, and implemented the first successful copper porphyry exploitation procedure at Bingham Canyon. According to Parsons (1933: 53), the report of Bingham Canyon produced by Jackling and Gemmell was "the first conservative and reasonably comprehensive analysis of a mining enterprise based on the exploitation of ore containing as little as $2 \%$ copper." After the success of Bingham Canyon, Jackling participated in the start-up of many other porphyry deposits in the United States and the rest of the world, later identified as the "father" of open-pit copper mining (Parsons, 1933; Hyde, 1998; Bridge, 2000).

Other North American engineers who stood out for their participation in the development of open-pit copper mining were the mining engineer Pope Yeatman and the chemical engineer Elias Cappelen-Smith, who explored, designed, and commissioned the Chuquicamata mine.

At the beginning of the $20^{\text {th }}$ century, numerous articles in US and Chilean newspapers, magazines, and books focused on the construction processes of the porphyries copper

15 Even after the Guggenheims no longer held a controlling stake in Chuquicamata, all company decisions were made directly in New York. An example of this process relates to the negotiation between the Chile Exploration Company and the Municipality of Tocopilla for the purchase of electricity in 1930. The General Manager in Chile, Mr. Burr Wheeler, told the press that he had made the request by airmail to the New York address to sell electricity to the city (LPT, 1930).

16 In 1900, after his first visit to Bingham Canyon, Jackling obtained a degree in Metallurgical Engineering at the Missouri School of Mines (Caldwell, 2015). 
mines in the United States, Chile, and all around the world. Frequently, these works were described as true "engineering feats" (Bruschel, 1915: 202) carried out by exceptional men who were able to overcome every challenge that nature put before them. For instance, in 1917 the journal The Wallace Miner of Idaho suggested:

Look at the great mines of the day and consider what they would be without brains. The entire group of porphyry coppers would be simply worthless rock peppered with a little copper had it not been for the genius of Jackling in leading the way...It was no great feat for the Guggenheims to supply $\$ 15,000,000$ for the development of Chuquicamata after Yeatman had worked out the engineering and Cappelen-Smith the metallurgy. (TWM, 1917: 6)

In this context, the images of these engineers (Jackling in Utah and Yeatman and Cappelen-Smith in Atacama) were lauded as techno-heroes. Armed with their inventiveness, work ethic, and technological knowledge, they were seen as capable of extracting the mining wealth from the bowels of the earth and using it in the service of national progress. However, all this progressive discourse regarding the limitless ingenuity of the US engineer in overcoming nature's obstacles concealed another aspect of the mega-mining invention: its socio-environmental costs. Accordingly, this "historical amnesia" (LeCain, 2009: 4) meant that the hundreds of tons of toxic waste (solid, liquid, and gaseous) that were generated to produce one pound of copper were overlooked.

Additionally, these techno-hero tales obscured from the popular imagination the hundreds of underpaid and "low-skilled" ${ }^{17}$ immigrants and workers who facilitated the movement of the railroads that drove the steam-shovels in the pit or carried out the risky smelting operations at Bingham Canyon and the electrolysis in Chuquicamata. Moreover, in the Chilean case, these discourses tirelessly depict a desolate and empty landscape on which foreign companies built the mine facilities, using terms such as "barren Chilean pampa" (Brushnell, 1915: 202) or "barren desert" (MEW, 1914b: 948) to describe the Chuquicamata area. Except for a few references to pre-Hispanic mining, these perspectives ignore the millenary history of complex local production in the central Andean region.

In economic terms, even though the new method of copper porphyry exploitation required vast amounts of initial investment in research, technology, and development, these initial "risks" were quickly outweighed by the exorbitant profits generated (Girvan, 1972). Moreover, this mass production of copper created an image of open-pit mining as a "low cost" and "efficient" method of production. This conception of efficiency was based exclusively on profit maximization and cost minimization and could be considered "technological rationality" (e.g., Marcuse,

\footnotetext{
17 Peck (1993: 158) uses the concept "unskilled immigrants" to refer to immigrants brought to work in the Bingham District with no previous mining experience. However, in other contexts it is used to explain the low wages received, even though after a few months the field workers were able to perform jobs that required great skill.
} 
2004). From this perspective, the new technologies for the extraction and refinement of copper porphyries were "purified" of all socio-natural costs.

Put simply, while the Guggenheims accumulated profits, the high cost of structural violence (Galtung, 1969) and slow violence (Nixon, 2011) accumulated over a period of decades for workers and territories where open-pit mining projects were implemented. In this aspect, one of the most emblematic socio-environmental impacts of both extraction territories was (and still is) air pollution through the emanations of smelters and thermoelectric power plants. In the case of smelters, the emanation of sulfuric acid and other pollutants produced by several sites (among them an ASARCO facility) caused significant losses for Salt Lake Valley farmers during the first years of the $20^{\text {th }}$ century. After a lengthy trial dubbed the "smoke suite," in 1909 the companies were forced to cut their emissions. In just a few months, the first system to recover sulfuric acid from smelter emissions was created and installed at the new plant built in Garfield by ASARCO (Whitehead \& Rampton, 2006). In the Chilean case, Gutiérrez and Figueroa (1920) point out that in 1916 several deaths were reported in the workers' camp due to smelter emissions, which were hidden in official reports.

Relatedly, cases of lung diseases at Bingham Canyon (Davis, 1989) and Chuquicamata (Finn, 1998), air pollution at Bingham Canyon (Hansen, 1963) and Tocopilla (GalazMandakovic, 2017; 2018), as well as water dispossession in the Andes (Prieto, 2015; Prieto et al., 2019) all became common occurrences. Furthermore, behind the "safety first" policy, there was a high occupational accident rate. Though we lack precise numbers, different accounts from doctors and workers at Bingham (Frazier, 1965; HDA, 2017) and workers at Chuquicamata (Gutiérrez \& Figueroa, 1920) allow us to conclude a significant accident rate at both mines. As Ross (2019: 150) proposed, "the costs of mining were passed on to others downstream."

Concerning the burning of fossil fuels, during the studied period, Bingham's smelting furnaces and power plants alternated between coal and oil (Arrington \& Hansen, 1963). In the case of Chuquicamata, the smelting furnaces operated with coal brought by ship from Baltimore (AGPT, 1919), while the thermoelectric plant installed in Tocopilla ran with oil purchased from the Union Oil Company and shipped from California (TWSJ , 1920).

From the outset, the mass production technology used for copper porphyries, conceived by J ackling, was based on the reduction of large volumes of rock to powder for the subsequent extraction of marketable minerals. As exposed by LeCain (2009: 6$8)$, the mass production and mass consumption of copper were inextricably intertwined with the "mass destruction" of mountains, rivers, lakes, and communities who lived near the copper mines. Blind to this environmental degradation, the sociopolitical context of the mass consumption of copper during the late $19^{\text {th }}$ and early $20^{\text {th }}$ centuries allowed capital to expand and rapidly produce mining territories. In this sense, the mass destruction of the socio-environmental aspects brought about by the 
open-pit mining proposed by LeCain (2009) is an entangled byproduct of the mass production of teleconnected miningscapes around the world.

As a clear example, the project devised by Jackling would not have been possible without the legibility of subterranean territories, the physicochemical characteristics of copper porphyry ore, the massive investment made by the Guggenheim family, or the large numbers of underpaid workers needed to produce the open-pit miningscapes. The introduction of capital from large corporations spatially reconfigured power relations, along with the conditions and flows of cost and benefits of the mining projects, producing different socio-environmental realities depending on the scale: local, national, or global.

In a context of high demand for the red metal, the Guggenheims' economic power allowed them to engage a team of engineers and geologists who were making legible mining projects around the world. This economic and technical management system was based upon a centralized decision-making process, which allowed them to apply to each of their projects the improvements discovered when studying a different deposit's particularities. On the other hand, the material particularities relating to the open-pit mining of copper porphyries led to a concentration of adverse effects in the actual mines and the surrounding territories. At the same time, the decisionmaking capital centers continued to serve as home to the vast majority of profits. This scenario leads us to propose that the Bingham Canyon and Chuquicamata miningscapes (and other porphyry copper projects managed by the family) operated as a single mine, meaning that the production of the Guggenheim open-pit miningscapes operated in a teleconnected way.

5.3 Mining Fordism in Utah and Atacama: Labor exploitation in the center of the open-pit era

As proposed by Arrington and Hansen (1963) and Emel and Uber (2011), the exploitation management of copper porphyries implemented by Jackling and the Guggenheim group can be understood as the first "Fordist" mass production project in mining. Ironically, this capital and technology-intensive "assembly line" (from steamshovel extraction to railroad transportation, to concentrating and smelting, to further railroad transport to the markets) required the input of massive numbers of underpaid workers (Peck, 1993; Emel \& Uber, 2011). Thus, while these mega-projects caused dramatic environmental effects, they were also characterized by uneven capital-labor relations.

In this context, during the first decades of operations, the UCC administration engaged workers from Greece, Italy, J apan, and other European countries in order to pay a rate that was half of that demanded by US workers for the same labor (Caldwell, 2015). Following the same strategy, the Chuquicamata mine workforce was mainly composed of Bolivians, mestizos, and rural inhabitants of southern Chile (Unger \& Unger, 2005). Hence, the low cost of the porphyries production was effectively subsidized by workers whose labor contracts were established with obscure dependency methods, such as the "padrone system" in the case of Bingham 
Canyon (Papanikolas, 1965; Peck, 1993), or with strict coercion measures in the case of Chuquicamata (Unger and Unger, 2005; Gutierrez, 2008)

The first conflict between workers and the UCC occurred in September 1912. At this time, the Western Federation of Miners went on strike, demanding a fifty-cents-perhour raise. In response, the firm (backed by the US government) sent 50 sharpshooters from the National Guard and armed another 400 local men to halt the workers' uprising. Saloons and gambling houses were closed, and all the mines and railroad crossing were floodlit by Utah authorities. The company also brought in strikebreakers from other communities (mainly Mexicans and Italians), including some forced labor. By the end of October, half of the workers had returned to their posts and, in November, the mines were once again functioning normally (USIFA, 1941; Peck, 1993).

In the Chilean case, even though the magazine Mining and Engineering the World indicated that "the Chilean workmen have proved very satisfactory and they seem more than content with the wages and the living conditions at Chuquicamata" (MEW, 1914b: 948), Ortiz (1985) affirmed that the first strike movement in Chuquicamata took place within a few months after the opening of operations: on July 1, 1915. The strike lasted for a week, but the miners were unsuccessful in having their demands met by the administration. ${ }^{18}$ Then, in late 1919, a group of mineworkers walked off the job in support of the railroad workers' strike. The company, backed by the Chilean police (locally known as the Carabineros), expelled 40 families of strikers and arrested several leaders of the Sindicato de Union Obrera (Workers' Union Alliance) (Unger \& Unger, 2005). Following this episode, CHILEX established an alliance with the police, who agreed to install a checkpoint at the outskirts of the mine. Chilean police officers were hired as CHILEX employees and became the principal means of suppressing any hint of a strike or other labor conflict. Apparently, after a couple of decades of coercive control, the "natives" were "domesticated." In this respect, Rudolph (1951: 89) indicated that "twenty years ago they were the rotos. ${ }^{19}$ The 'ragged ones'; now they are self-respecting Chilean citizens."

Additionally, since its conception in New York in 1912 (Illanes, 1915), the mining camp was designed in a segregated way: a section for North American and European engineers and professionals and another section for the local workers. The design meant that North American executives received houses with six bedrooms and two bathrooms, while local workers with families received a house with two or three rooms (one-fifth of the surface area of executive houses) (Unger \& Unger, 2005: 30)

18 The principal requests were: eight hours of work, $25 \%$ salary rise, an hour and a half for lunch, school access for the workers, and a reduction in the grocery store's prices, among others (Ortiz, 1985).

19 The term "roto" is a degrading concept used to characterize poor and ragged Chilean workers (Gutiérrez, 2010). 
and the single men were housed in common barracks that had bathrooms at the ends of corridors or in an outdoor area (IIlanes, 1915; Gutierrez, 2008). ${ }^{20}$

The spatial and administrative organization of these company towns (mainly associated with the production of extractive commodities) was designed in corporate boardrooms to prevent the socializing of workers with the outside world, thereby ensuring greater control over them. In this way, workers would be more productive (Porteous, 1970). Following this idea, the architectural design of the Chuquicamata miningscape aimed to reproduce the labor force.

These uneven conditions provoked critical reactions from the Chilean historians Eulogio Gutiérrez and Marcial Figueroa, who wrote several books describing this inequity (Gutiérrez \& Figueroa, 1920; Gutiérrez, 1926; Figueroa, 1928).

More insidiously, even though the management of the workers in both projects developed in similar ways, the socio-environmental and political conditions of the Chuquicamata site allowed GUGGENEX to build a company town through which it exercised panoptic control over all aspects of the workers at Atacama.

\section{Conclusions: The open-pit era and the tele-production of miningscapes}

The rise of the use of electricity to produce goods and simply in everyday life, along with the utilization of brass in construction and other manufacturing, led to a worldwide explosion in the demand for copper at the end of the $19^{\text {th }}$ and early $20^{\text {th }}$ centuries. During this period, high-grade deposits were depleted (Ross, 2019) and it was necessary to create new methods for the exploitation of low-grade minerals (copper porphyries). In this context, large corporations were in a position to finance the long-term processes of mining development, hire the most advanced scientific capital at the time, and carry out different tests to determine the best protocols for milling, concentrating, and smelting the copper, along with constructing machinery that could be adapted to the particular characteristics of each ore. Consequently, the creation of a new economic and technical strategy to obtain economic profit from the exploitation of copper porphyry ores (open-pit mining) caused a dramatic expansion in copper production.

In the process of creating and capturing value from the particular mineralogical properties of the porphyries, the capital of the economic groups was used to extensively study and test processes to assess whether the extent and quality of the ore deposits were economically viable. Subsequently, a continuous research process was initiated, focused on manufacturing and using the most advanced technology in the process of mineral purification to obtain an increasing profit margin, based on mass production and a decrease in the cost of each unit produced. Thus, the capital

20 According to Unger and Unger (2005: 130), this racialized and hierarchical structure of spatial administration was a repeated pattern in other projects administered by the Guggenheims. 
of the Guggenheim group and the technical skills of the dozens of engineers who worked on the development of the project came together to transform mountains of low-grade minerals into mountains of money, leaving behind a trail of pollution and inequality.

The transformation of low-grade copper into profitable commodities required largescale exploitation and the invention of new mechanical and metallurgical procedures to enable it. This mining method implies the emergence of complex teleconnections between economic centers and mining territories: knowledge, technology, wealth, water, workers, and copper, among others, that were hegemonically articulated by economic groups. Thus, while wealth was accumulated in centers of power, inequality, disease, pollution, dispossession, and other problems occurred at a local level which, in turn, led to uneven yet teleconnected miningscapes. With this in mind, we suggest that capital in dialog with scientific knowledge produced Utah and Atacama as miningscapes that, together, articulate a single system of wealth production and inequality.

Further, it is important to point out that these porphyry copper miningscapes were teleconnected to other extractive territories (coal mines in Utah and Virginia, as well as oil wells in California), which illustrates the multi-scale nature of these megaprojects. Likewise, the implementation of this business model required the crucial presence of modern state institutions to facilitate the enclosure of common resources (Heynen \& Robbins, 2005). To this end, property regulation systems guaranteed the appropriation of natural resources and the legal use of physical force against any miners or local communities who were in conflict with mining companies.

Based on the studied cases, we propose that the social, political, and economic conditions of the first years of mining at Bingham Canyon (1903-1923) and Chuquicamata (1915-1923) resulted in the banning and suppression of any social manifestation of conflict (labor or socio-environmental) against these projects. These artificially stable conditions allowed the open-pit copper mining model of exploitation to produce unequal territories. On the one hand, there were the "sacrificed territories" -the sites where the minerals were extracted and processed (Bingham and Chuquicamata). On the other, there were the "accumulation territories" - the places where the economic benefits were received (Manhattan). In this way, from the meeting room located at the core of Manhattan, New York, based on strictly technical and economic parameters, the Guggenheim group controlled the tele-production of these miningscapes.

We suggest that the study of the teleconnected production of miningscapes opens an expansive perspective for understanding the commodification of nature as a multiscalar and teleconnected process of the expansion of capitalism. In this sense, we believe that this perspective, the study of miningscapes (Stoltenborg $\&$ Boelens, 2016; Méndez, Prieto \& Godoy, 2020), and the analysis of labor networks, production, and consumption processes addressed by the literature on Global Commodity Chains (Bair, 2009) are complementary approaches to the study of productive, commercial, 
geographic, and power relations, among others, established in the context of global capitalist expansion.

Finally, the teleconnected production of miningscapes affords the potential for critical reflection on "empire states" or "imperialism." In this case, the mining of copper porphyries by a particular economic group demonstrates that a hegemonic position can be dissociated from national borders and entangled with capitalism as a mode of production of uneven territories.

\section{References}

\section{1 Handwritten sources}

Archivo Nacional de la Administración (ARNAD). Fondo Ministerio de Obras Públicas (MINOP).

Volumes 1089 - 2367 - 2535

Archivo Gobernación Provincial de Tocopilla (AGPT). (1919). Oficio N545. 30 Julio 1919.

\subsection{Other sources}

ADGER, N., EAKIN, H. and WINKELS, A. (2009). Nested and teleconnected vulnerabilities to environmental change. Frontiers in Ecology and the Environment, 7(3), p.150-157.

ARRINGTON, L. and HANSEN, G. (1963). "The richest hole on earth". A history of the Bingham copper mine. Logan, Utah State University Press.

BAIR, J. (2009). Global commodity chains: genealogy and review. In: J. Bair (Ed.), Frontiers of commodity chain research. Palo Alto, Stanford University Press, p. 1-34.

BRAUN, B. (2000). Producing vertical territory: Geology and governmentality in late Victorian Canada. Ecumene, 7(1), p.7-46.

BRIDGE, G. (2000). The social regulation of resource access and environmental impact: production, nature and contradiction in the US copper industry. Geoforum, 31, P.237-256.

CALDWELL, H. (2015). A Kennecott story: Three mines, four men, and one hundred years, 1887-1997. Salt Lake City, University of Utah Press.

CHILE EXPLORATION COMPANY (CHLEX). (1958). Chuquicamata. El mineral de cobre más grande del mundo. Chuquicamata, The Anaconda Company. 
CLUNY, C. (2000). Atacama. Essai sur la guerre du Pacifique 1879-1883. Paris, Editions de La Différence.

DAVIS, J. (1989). The Guggenheims. An American epic. New York, Spi Books.

DONALD, M. (1936). History of the Chile nitrate industry II. Annals of Science, 1(2), p.193-218.

EAKIN, H., WINKELS, A. and SENDZIMIR, J. (2009). Nested vulnerability: exploring cross-scale linkages and vulnerability teleconnections in Mexican and Vietnamese coffee systems. Environmental Science \& Policy, 22, p.398-412.

EMEL, J. and HUBER, M. (2011). The richest hole on earth? Nature, labor and the politics of metabolism at the Bingham Canyon copper mine. In: S. Brunn (Ed.), Engineering earth. The impacts of megaengineering projects. New York, Springer. Vol. 1, p.353-366.

FIGUEROA, M. (1928). Chuquicamata: la tumba del chileno. Antofagasta, Imprenta Castellana.

FIGUEROA, V., SALAZAR, D., SALINAS, H., NÚÑEZ-REGUEIRO, P. and MANRÍQUEZ, G. (2013). Pre-Hispanic mining ergology of northern Chile: an archaeological perspective. Chungará, Revista de Antropología Chilena, 45(1), p.61-81.

FINN, J . (1998). Tracing the Veins: Of copper, Culture, and Community from Butte to Chuquicamata. Berkeley, University of California Press.

FRAZIER, R. (1965). Bingham Canyon through the eye of a company doctor. Utah Historical Quarterly, 33(4), p.283-288.

GALAZ-MANDAKOVIC, D. (2017) Inclusions, transformations et asymétries du capitalisme minier sur la côte d'Atacama : les dérives de la production thermoélectrique à Tocopilla (Chili) 1914-2015. PhD. Thesis Instituto de Arqueología y Antropología, Universidad Católica del Norte (Chile) and Université Rennes 2 (France).

GALAZ-MANDAKOVIC, D. (2018) Desechos, aluviones y racismo de Estado. El caso de la población Pacífico Norte de Tocopilla (Chile) 2009-2015. Rumbos, (17), p. 97-130.

GALTUNG, J. (1969). Violence, peace, and peace research. Journal of peace research, 6(3), p.167-191.

GIRVAN. N. (1972). Copper in Chile: A study in conflict between corporate and national economy. Jamaica, University of West Indies. 
GRIMM, R. (2002). Notable American Philanthropists: Biographies of Giving and Volunteering. New York, Greenwood Publishing Group.

GUTIÉRREZ, E. (1926). Chuquicamata, Tierra Rojas. Historia y monografía. Santiago, Editorial Nascimento.

GUTIÉRREZ, E. and FIGUEROA, M. (1920). Chuquicamata: Su grandeza y sus dolores. Santiago, Imprenta Cervantes.

GUTIÉRREZ, H. (2010). Exaltación del mestizo: La invención del roto chileno. Universum, 25(1), p.122-139.

HANSEN, G. (1963). Industry of destiny: Copper in Utah. Utah Historical Quarterly, 31(3), p.262-279.

HERALDO DE ARAGÓN (HDA) (2017). De jalaboyas al sueño Americano. https:/ / www. heraldo. es/ noticias/ aragon/ teruel/ 2017/ 11/ 26/ de-jabaloyas-suenoamericano-1210308-2261128. html

HEYNEN, N. and ROBBINS, P. (2005). The Neoliberalization of Nature: Governance, Privatization, Enclosure and Valuation. Capitalism Nature Socialism, 16(1), p.5-8.

HYDE, C. (1998). Copper for America. The United States copper industry from Colonial times to the 1990s. Tucson, The University of Arizona Press.

HOYT, E. (1967). The Guggenheims and the American dream. New York, Funk and Wagnalls.

ILLANES, G. (1915). Mineral de Chuquicamata de la Chile Exploration Company (inaugurado el 18 de mayo de 1915). Santiago, Imprenta Universitaria.

KRAHULEC, K. (2010). Production history of the Bingham Mining District, Salt Lake County, Utah. In K. Krahulec and K. Schroeder Eds. Tops and bottoms of porphyry copper deposits: The Bingham and Southwest Tintic District, Utah. Littleton, Society of Economic Geologist. p. 25-50.

LA PRENSA DE TOCOPILLA (LPT). (1930). La Chile Exploration consulta venta de energía el éctrica a la Municipalidad. 4 junio 1930.

LIU, J., DIETZ, T., CARPENTER, S., FOLKE, C., ALBERTI, M., REDMAN, C., SCHNEIDER, S., OSTROM, E., PELL, A., LUBCHENCO, J., TAYLOR, W., OUYANG, Z., DEADMAN, P., KRATZ, T. and PROVENCHER, W. (2007). Coupled human and natural systems. AMBIO: A J ournal of the Human Environment, 36, p.639-649.

LIU, J., HULL, V., BATISTELLA, M., DEFRIES, R., DIETZ, T., FU, F., HERTEL, T., IZAURRALDE, C., LAMBIN, E., LI, S., MARTINELLI, L., MCCONNELL, W., MORAN, E., 
NAYLOR, R., OUYANG, Z., POLENSKE, K., REENBERG, A., ROCHA, G., SIMMONS, C., VERBURG, P., VITOUSEK, P., ZHANG, F. and ZHU, C. (2013). Framing sustainability in a telecoupled world. Ecology and Society, 18(2): 26.

MARCUSE, H. (2004). Some social implications of modern technology. In: H. Marcuse (Ed.), Technology, War and Fascism (Vol. 1). Routledge, New York, p. 59-86.

MARTINEZ, G. (1943) Orígenes y desarrollo de Chuquicamata bajo la Chile Exploration Company. Santiago, Ediciones Revista Universitaria.

MENDEZ, M., PRIETO, M., GODOY, M. (2020). Production of subterranean resources in the Atacama Desert: $19^{\text {th }}$ and early $20^{\text {th }}$ century mining/ water extraction in the Taltal district, northern Chile. Political Geography, 81, p.1-12.

MINING AND ENGINEERING THE WORLD (MEW). (1914a). Mastic lining for acid tanks adopted by Chile Exploration Co. Editorial Correspondence, March 28, 1914. Vol.40, p. 548 and 1207.

MINING AND ENGINEERING THE WORLD (MEW). (1914b). Progress being made by the Chile Copper Company. Editorial Correspondence, November 21, 1914. Vol.41, N²1, p. $947-949$.

MINING AND ENGINEERING THE WORLD (MEW). (1915). Chile Copper Co, ready for operations. Editorial Correspondence, May. 29, 1915. Vol.42, p. 983-984.

MOORE, J. (2000). Sugar and the expansion of early modern world-economy. Commodity frontiers, ecological transformation, and industrialization. Review (Fernand Braudel Center), 23(3), p.409-433.

NIXON, R. (2011). Slow violence and the environmentalism of the poor. Cambridge, Harvard University Press.

O'BRIEN, T. (1989). Rich beyond the dreams of avarice: The Guggenheims in Chile. The Business History Review, 63(1), p. 122-159.

O'CONNOR, H. (1937). The Guggenheims. The making of an American dynasty. Ney York, Covici Friede Publishers

ORELLANA, L. (2004). La lucha de los mineros contra las leyes: Chuquicamata (19001915). Historia, 37(1), p.169-20.

ORTIZ, F. (1985). El movimiento obrero en Chile: 1891-1919. Madrid, Eds. Michay.

PAPANIKOLAS, H. (1965). Life and labor among the immigrants of Bingham Canyon. Western Historical Quarterly, 33(4), p.289-315. 
PARSONS, A. (1933). The porphyry coppers. New York, The American Institute of Mining and Metallurgical Engineers.

PECK, G. (1993). Padrones and protest: "Old" radicals and "new" immigrants in Bingham, Utah. 1905-1912. Western Historical Quarterly, 24(2), p.157-178.

PORTEOUS, J . (1970). The Nature of the Company Town. Transactions of the Institute of British Geographers, 51, p.127-142.

PRIETO, M. (2015). Privatizing water in the Chilean Andes: The case of Las Vegas de Chiu-Chiu. Mountain Research and Development, 35(3), p.220-229.

PRIETO, M., SALAZAR, D. and VALENZUELA, M. (2019). The dispossession of the San Pedro de Inacaliri river: Political Ecology, extractivism and archaeology. The Extractive Industries and Society, 6(2019), p.562-572.

RICKARD, T. (1932). A history of American mining. New York, McGraw-Hill Book Company, Inc.

ROSS, C. (2019). Ecology and power in the age of Empire. Europe and the transformation of the tropical world. Oxford, Oxford University Press.

RUDOPLH, W. (1927). The Rio Loa of Northern Chile. Geographical review, 17(4), p. 553-585.

RUDOPLH, W. (1951). Chuquicamata Twenty Years Later. Geographical review, 41(1), p. 88-113.

SCOTT, J. (1998). Seeing like a State. How certain schemes to improve the Human condition have failed. New Heaven, Yale University Press.

STOLTENBORG, D. and BOELENS, R. (2016). Disputes over land and water rights in gold mining: the case of Cerro de San Pedro, Mexico. Water International, 41(3), p.447467.

THE WALLACE MINER (TWM). (1917). Value of brains in successful mining. Chronicling America: Historic American Newspapers. Lib. of Congress. বhttps:// chroniclingamerica. loc. gov/ Iccn/ sn85007266/ 1917-11-22/ ed-1/ seq-6/ >

THE WALL STREET J OURNAL (TWSJ ). (1920). Chile Copper. Aug. 4, p.11.

TITLEY, S. (1972). Intrusion, and Wall Rock, Porphyry Copper Deposits. Economic Geology 67(1), p.122-123.

UNGER, I. and UNGER, D. (2005). The Guggenheims. A family history. New York, Harper Prennial. 
UNITED STATES GEOLOGICAL SURVEY (USGS). (1905). Economic geology of the Bingham Mining District, Utah. Washington, Government Printing Office.

UTAH STATE INSTITUTE OF FINE ARTS (USIFA). (1941). Utah, a guide to the State. Compiled by workers of the writers' program of the Work Projects Administration for the State of Utah. New York, Hasting House Publishers.

WALLACE, J and GUTZLER, D. (1981). Teleconnections in the Geopotential height field during the Northern Hemisphere winter. Monthly Weather Review, 109, p.784-812.

WHITEHEAD, B and RAMPTON, R. (2006). Bingham Canyon. In Colleen Whitley Ed. A history of mining in Utah. Denver, University Press of Colorado, Ch. 10, p.220-249.

WRIGHT, P. (1977). The southern oscillation-patterns and mechanism of the teleconnections and the persistence. Hawaii: Hawaii Institute of Geophysics, University of Hawaii. 